\title{
17 \\ CONCEPTUAL FALLACIES AND OPEN QUESTIONS ON POST-FORDISM
}

\author{
Danièle Leborgne and Alain Lipietz
}

\section{INTRODUCTION}

In the second half of the 1980s, hopes were kindled about the emergence of a new and seemingly progressive model of capitalist development. Post-Fordism appeared as a candidate for the way out of the crisis of dominant postwar economic model, Fordism. These new hopes emerged from old fears about what seemed to be the dominant (and regressive) solution in the first half of the decade, "neo-Fordism." This change in mood among radical economists and geographers relies upon the fact that in the world battle between two ways out of the crisis of Fordism, the countries that seem to be victorious (e.g. Japan, Germany, the Nordic countries) have developed more positive forms of compromise between capital and labor than the losers in competition (e.g. USA, UK, France). Moreover, this change in the mood expresses a more constructive attitude: instead of complaining that things are getting worse and worse, propositions are addressed to unions, communities, political forces, and "enlightened" managers designed to promote a positive-sum compromise.

The new conventional wisdom of the first half of the 1980s may be summarized as follows. New technologies tend to foster the separation between highly skilled designers and engineers, and poorly skilled operatives. Since these operatives should be hired at the lowest price (and not at an "efficiency wage"), it would be useless for capital to respect the wage level of the collective bargaining system, and to finance a costly welfare state. The consequence is that advanced capitalist societies would evolve towards "two-tier," "hourglass," Brazilian-type societies. Moreover, the shift of routinized production towards the Third World would lead to a deindustrialization of the developed world. In the upper tier of the latter, the yuppies and golden boys of high-tech and finance would flourish, managing principal world-scale corporations, while women, ethnic minorities, and deskilled male workers would survive by working in the service of the upper tier. That would be a form of Fordism without the advantages of Fordism: a neo-Fordism. ${ }^{1}$

After 1983, the gloomy atmosphere of the "monetarist shock" was replaced by the world recovery symbolized by the miracle economies of Japan, Korea, the Third Italy, and Baden-Württemberg. A new discourse, "post-Fordism," emerged to give these successes a theoretical framework. Post-Fordism is based on a shift from "mass production" to "flexible specialization," in which craft work takes place in networks of interconnected, independent, specialized, and flexible firms, which are in a position to react quickly to changes in fashions on the world market and to implement efficiently 
new technologies. Based on preexisting local resources of capital and skills, new growth regions emerge through the spinoff of innovative firms or through disintegration of big companies. ${ }^{2}$

Neither the objective situation nor the debate is so clear-cut. First, many scholars collapse the two models into one single "craft-flexible post-Fordism" 3 and, in so doing, they eclectically reflect a still confusing reality. Second, claims about the positive aspects of post-Fordism (i.e. reskilling of the labor force, human-scale productive systems) are called into question by evidence of growing neo-Fordist regressive tendencies in many parts of the world economy, including the USA, the UK, and southern Italy. Moreover, the world concentration of capital raises some doubts about the importance of network production. ${ }^{4}$

Strangely enough, both sides in the debate refer to French regulation theory, especially through the reference to the Fordist paradigm. "Fordism" was a term coined by Antonio Gramsci in his analysis of historical blocs as political keystones of development. Yet most participants in the post-Fordist debate reduce it to a debate about new production systems and, contrary to most French regulationists, hold that there is already a solution, whether neo-Fordist or post-Fordist, to replace Fordism. ${ }^{5}$

In this chapter, we will begin by referring back for our definition of Fordism, after which we will discuss some common fallacies in the post-Fordism thesis. We focus on post-Fordism rather than on neo-Fordism because the latter has really been implemented in the USA and UK, and it is now seriously challenged by something else that some have labeled post-Fordism, and which is certainly more interesting, both theoretically and politically. We discuss five open questions with respect to the notion of post-Fordism.

1 A model of development is not only a technological paradigm. Fordism was not just "mass production," nor could post-Fordism be defined merely as "flexible specialization."

2 There is no single way out of the crisis of Fordist labor relations. Neo-Fordism and post-Fordism are conflicting solutions, because neo-Fordist "flexibility" and postFordist "craft" cannot be mixed at will.

3 Industrial organization is also an open issue. There are still contests between big corporations and industrial districts, as well as between different forms of industrial nerworks.

4 Macroeconomics still matters, and ecology matters more and more; the free market will not be the form of regulation of post-Fordism.

5 There is no reason why a single model of development should be world-hegemonic. After-Fordism will very likely not consist of the victory of only one of the conflicting models, but a core-periphery in which the two coexist.

\section{A DEVELOPMENT MODEL IS NOT SIMPLY A TECHNOLOGICAL PARADIGM}

Much of the post-Fordist discourse is based upon the idea of a return of craft production. By craft production is usually meant both the supply-side (skilled workers committing their knowledge into the fine-tuning of a flexible technical apparatus) and a demand side 
(customized commodities serving volatile and fragmented demand). New technologies are said both to provide an answer to the need for flexibility of the demand, and in turn to require a specialized labor force. And this leads, so it goes, to flexible specialization as a model of capitalist development, and it in turn is equated with post-Fordism per se. Fordism, by contrast, was based on mass production, with its rigid assembly lines requiring low skills, and producing standardized commodities.

This presentation of history is based on a dangerous technological determinism. A system such as Fordism is a complete way of living, rooted in a historical bloc, yet these analyses reduce it to the logic of a production system. While it is necessary, for any model of production to achieve stability, that there should be a consistency between the organization of production, labor relations, the pattern of consumption, and even social ideologies of progress, such consistency is a chance discovery of history, the result of a process of social and political learning (Lipietz 1985). Conflicting solutions are possible on the basis of a given set of technologies and they are not determined by the technological paradigm. Let us illustrate this point by taking up the example of Fordism. As a model of development, Fordism has three main dimensions.

- As a general principle of organization of labor or technological paradigm, ${ }^{6}$ Fordism is nothing more than Taylorism plus mechanization. Taylorism implies a strict separation between conception labor, which is the task of the Organization and Methods Office $(\mathrm{O} \& \mathrm{M})$ on the one hand, and the execution of standardized and formally prescribed tasks on the shopfloor on the other hand. Mechanization embodies the collective knowledge of $\mathrm{O} \& \mathrm{M}$ into the material apparatus. Reduced to these dimensions Fordism induces mass production. Yet the implementation of this technological paradigm in the 1920s raised a serious question. Who would buy the outputs of mass production? Henry Ford is now famous for having proposed an answer: wage earners should be the main customers. Hence the name of Fordism for the macroeconomic pattern which was eventually implemented twenty years after the Great Depression, which was the underconsumption crisis stemming from mass production.

- As a macroeconomic pattern (or regime of accumulation), Fordism implied that the gains in productivity arising from its principles of production were matched, on the one hand, by the increase of investments financed by profits, and on the other hand by the increase in purchasing power of the waged workers. As a result, both the share of wages in value-added and the value capital/output ratio were roughly constant, the rate of profit was essentially stable, and the markets for production goods and consumption goods both grew in pace with productivity. But - and here Henry Ford had less to say than Keynes and Beveridge - how could such a steady increase in purchasing power be achieved? Here rules of coordination between economic agents had to be established. Fordism cannot exist in a single firm.

- As a system of rules of coordination (or as a mode of regulation), Fordism implied long-term contracts as the basis of the wage relation, with rigid limitation of layoffs, and a tying of wage increases to prices and overall productivity. Moreover, a large redistribution of revenues through the welfare state and social security insured a basic income for wage earners. The counterpart was the acceptance by the unions of managerial privileges, on the shop floor. As a result, both the principles of labor process organization and the macroeconomic pattern were respected. 
The crisis of Fordism has been subject to various explanations. In our analysis, its problems can be traced to supply and demand (Glyn et al. 1988; Lipietz 1985, 1989b). The most obvious reason appeared on the demand side. Competitiveness equalized between the United States, Europe, and Japan. The search for economies of scale induced internationalization of production processes and markets. The increase in the price of raw materials imported from the south (notably oil) stimulated competition for exports in the early 1970s. The regulation of the growth of domestic markets through wage increases was thus limited by the necessity to balance external trade. Faced with this demand-side crisis, the reaction of international elites was mainly Keynesian until the end of the 1970 s. Then the mood of the international elites of the capitalist world changed. Demandside management of the crisis had avoided a great depression, but a major and deeper limit became obvious: the fall in profitability.

This was due to a number of causes on the supply-side: a slowdown in productivity with increase in total labor price (including welfare payments), an increase in the capital - output ratio, and an increase in the relative price of raw materials. In those conditions, Keynesian strategies such as an increase in the real wage (however limited) and loose monetary policy could only induce inflation. Hence, the rise of monetarism (i.e. an attack on demand-side growth policies) and the shift to supply-side policies. In our view, the key to the supply side is industrial relations, which in turn encompasses aspects of the industrial production paradigm and the mode of regulation.

Even within the regulation approach, the supply-side problem of Fordism is subject to two interpretations. First, according to a Kaleckian analysis, the rise in the relative price of labor and raw materials was the result of the long boom of the "Golden Age" of the postwar period (Itoh 1980, Armstrong, Glyn, Harrison 1984). This "full-employment profit-squeeze" analysis became the official explanation in OECD reports by the end of the 1970s. Profits were too low because workers were too strong, and this was so because the rules of the game had become too "rigid." Liberal flexibility policies were adopted by the UK, then by American administrations, and were eventually implemented by a number of OECD countries, including even the socialist-communist French government in the 1980s (Lipietz 1990).

Yet a complementary explanation to the Kaleckian full-employment profit-squeeze theory stresses the exhaustion of the efficiency properties of Taylorism. In this view, it is not ultimately rational to eliminate all possibility of initiative on the part of the worker on the shop floor; "responsible autonomy" appears as a better principle, especially as the implementation of new technologies, or the shift to "just-in-time" management require the involvement of operators and their cooperation with managers and designers (Friedman 1977). ${ }^{7}$ This is precisely the labor process strategy selected by many successful firms in Japan, Germany, and Scandinavia.

Faced with these events, the notions of neo-Fordism and post-Fordism are on unequal ground. On the one hand, the neo-Fordist analysis acknowledges the main tendencies of the late 1970 s and early 1980 s, such as a progressive unraveling of the Fordist rules of the game (concession bargaining, development of secondary labor markets, cuts in the welfare state), enhanced by the monetarist shocks of 1979 and 1981, and inducing a dramatic transformation toward a new regime of accumulation, with a polarization of incomes, and a shift of social demand towards export and/ or toward the 
overconsumption of the upper tier of society (Davis 1986). Rather little is said about the changes within the technological paradigm, except to note a shift towards a "computerassisted Taylorism" (Mathews 1989). This analysis reflects rather well the way the USA dealt with its supply-side crisis.

On the other hand, the first theorizations of "flexible specialization" tried to capture the fact that some firms, regions, or countries were getting the better of the new world configuration brought about by monetarism. In a world of market volatility where customized commodities were favored by the new upper-middle classes, flexibility of supply was required, and specialized skills appeared as a better way to meet small batch demand. Since post-Fordism later on appeared as a new solution for the supply side of the crisis, it is indeed strange that these early theorizations insisted mainly on the demand side of the crisis (and wrongly characterized it as a crisis of "underconsumption"). ${ }^{8}$ The change in industrial relations appeared as an adaptation to a change in the regime of accumulation: post-Fordism in the plant as an adaptation to neo-Fordism in the world economy. This led to a failure to analyze the consistency of specialization and craft on the one hand, and flexibility in labor and product markets on the other hand. Moreover, flexible specialization as a new form of work organization was accorded a kind of neutrality in its macroeconomic effects: there would be no more problem of effective demand.

Yet, labor relations must be consistent. First, the different elements of the industrial relations system must be mutually consistent: wage contracts, labor organization, and the social reproduction of appropriately skilled labor forces. Second, they must be consistent with the broader shape of social life in concrete territories: general goals and accepted rules of life in a common society. Third, they should be consistent with the macroeconomics of some regime of accumulation or social structure of accumulation, both at the national and international level. Last, but not least, the global ecological situation is now imposing strong constraints on the generalization of most models.

We will reurn to the problems of macro consistency. But first let us scrutinize the consistency of flexibility and craft within labor relations itself.

\section{TWO PATHWAYS OF CAPITAL/LABOR RELATIONS}

When they characterize the actual evolutions of labor relations, scholars rightly notice that there are tendencies to flexibilize the wage contract (so as to reduce the direct and indirect cost of labor force), and tendencies to mobilize craft skills, know-how, and the intellectual activity of the labor force, in order to increase productivity, to adapt continuously the product to demand, and to increase the efficiency of a costly fixed capital. While a closer adaptation of supply to a volatile demand is a by-product of the latter, it represents a fundamentally different view of the way out of the supply-side crisis of Fordism. Are the two views compatible, as is sometimes held, where neo-Fordism and post-Fordism are combinable (Moulaert and Swingedouw 1989)?

The two views of the way out of the crisis may be thought of as two pathways of development of industrial relations, with a common starting point in Fordism: Taylorism as direct control by the management on the activity of workers, rigidity of the wage 
contract, as shown in Figure 17.1. ${ }^{9}$ The first pathway fosters an evolution from rigidity toward flexibility, the second one from direct control toward responsible autonomy. Stated differently, the first (vertical) axis refers to the external labor market, to the ties between firms and the labor power hoping to be hired. The second (horizontal), axis refers to the internal labor market, the forms of organization of cooperation/hierarchy within the labor process. ${ }^{10}$ It should be emphasized that compromises on the regulation of the "internal labor market" are not necessarily negotiated "inside" the firm.

On the first, "external" axis, there are several dimensions of rigidity and flexibility. Many dimensions of the external labor market may be regulated: the direct wage, hiring and firing, the social wage. The external market may be more or less organized. Moreover, such rules may be implemented at the level of individuals, professions, firms, sectors, or society. We shall not consider these details, however, because they are overdetermined by what happens on the other axis.

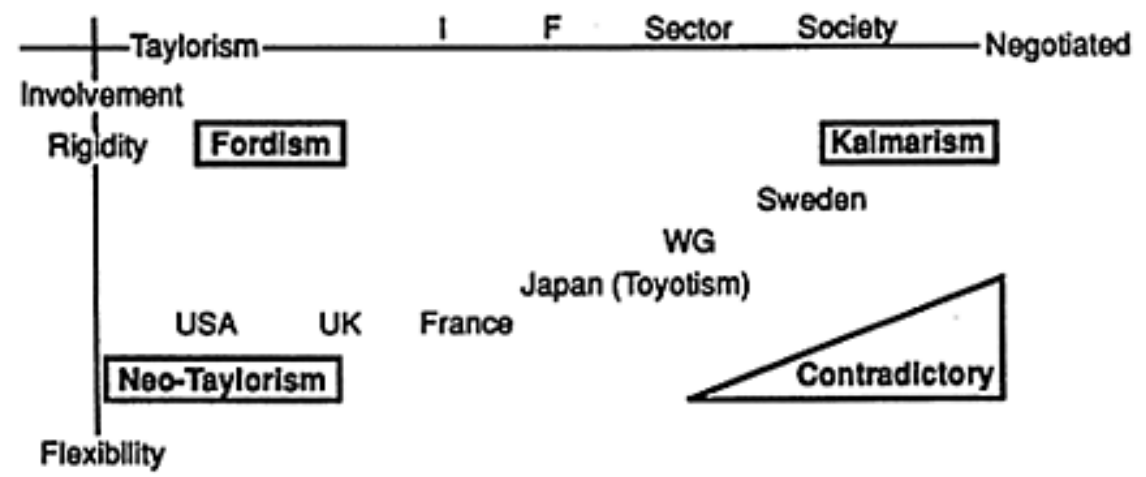

Figure 17.1 Post-Fordist industrial relations

On the second, "internal" axis, the degree of involvement also has several dimensions: upskilling, horizontal cooperation, participation in the definition and monitoring of tasks, and so on. For reasons that will appear shortly, we focus on the level of the negotiation of the compensation for the involvement of workers.

1 Involvement may by individually negotiated and rewarded by bonuses, career advancement, etc. This is limited by the collective character of the required involvement in most processes of cooperative production. "Individually negotiated involvement" (I in Figure 17.1) may be extended to a team or a shop.

2 Involvement may be negotiated firm-by-firm, between management and unions ( $\mathrm{F}$ in Figure 17.1). Here the firm and the work force share the rewards of the specific skills accumulated in the learning process. This implies an "(external) rigidity" of the wage contract, whose limit case is the "life-time" contract. 11

3 Involvement may be negotiated at the sector level ( $\mathrm{S}$ in Figure 17.1), thus limiting the firm's risk of competition from firms using cheaper labor, and inducing them to share skilling institutions. The external labor market is likely to be more organized, that is broadly speaking more rigid, with sector-wide collective bargaining, and a greater 
socialization of labor revenues.

4 The involvement may be negotiated at the level of the whole society, with unions and business negotiating at the regional or national level the social content and distribution of the production. In this case, it is understood that unions are responsible for worker performance on the shop floor. Here, the external labor market is likely to be at least as well organized as in the most advanced Fordist-corporatist cases. ${ }^{12}$

Nonetheless, collective involvement of the workers is unlikely to be possible if there is no commonality of destiny of firms and their work forces, i.e. in the context of external flexibility at any level. The outer limit of consistency between flexibility and involvement appears as the triangle marked on Figure 17.1. Collective involvement and flexibility are incompatible, and it is here that neo-Fordism and post-Fordism are so often conflated. ${ }^{13}$ It follows that there are two privileged lines of evolution i.e. two real pathways of development "after Fordism", which are shown in Figure 17.1:

a) External flexibility associated with hierarchical direct control: we are back to some form of Taylorist organization of the labor process, without the social counterparts of the "golden age" of Fordism. Let us call this paradigm neo-Taylorism.

b) External rigidity (organization) of the labor market associated with negotiated involvement of the workers. Let us call this paradigm Kalmarian, in honor of the first car factory reorganized according to the involvement principle in a social-democratic country: Sweden in 1974.

Looking back on the recent experience of the OECD countries, there is a range of experiences, with the USA and the UK privileging external flexibility and ignoring involvement, or introducing individually rewarded involvement (as in France), Japan practicing negotiated involvement at the firm level, Germany at the sector level, and Sweden being closer to the Kalmarian case. ${ }^{14}$ The firm-level negotiated involvement (typical of the Japanese case) allows for a dualistic coexistence of the two paradigms within a dualistic labor market (e.g. according to gender). ${ }^{15}$ This mixed situation could be labelled Toyotism.

The experience of USA shows that it is difficult to negotiate involvement at the shop or even plant level in a broader context of liberalism, with its high level of external flexibility. In the USA, individually negotiated involvement may, however, be developed. ${ }^{16}$

\section{INDUSTRIAL ORGANIZATION: STILL AT A CROSSROADS}

One of the main empirical tendencies of the 1980s was that "Big is Beautiful." Never in the history of capitalism has there been such a tremendous international centralization of capital. There are no more than five important European car makers and only two major alliances of aircraft-engine makers in the world. This has occurred in the context of a large increase in world industrial output since the early 1970s, at the twilight of Fordism. Nonetheless, advocates of a post-Fordism transition insist that non-vertically integrated forms of industrial organization are becoming dominant, with the rise of industrial districts. In this view, the new pattern of economic ownership should be the clustering of 
small- and medium-sized, specialized and flexible firms, based on a territorial sectorspecific supply of skilled workers. The paradigmatic examples of such a tendency would be the specialized productive areas of Third Italy, Silicon Valley, and so on. How is it possible to reconcile such different diagnoses? A first explanation may be sectoral specificities. Examples of industrial districts are usually found in the clothing, shoe, ceramic, software design, or customized electronic hardware industries, all of which are labor-intensive. On the contrary, concentration would be expected in capital-intensive industries, since even when economies of scope are important, they are increasingly internalized and based on costly flexible equipment. Internal economies of scale thus still matter when total output is considered. Still, even in highly centralized sectors, there are strong tendencies towards vertical disintegration, even within a given firm. It is from this latter phenomenon that the idea emerges of an organizational convergence between disintegrating corporations and quasi-intergrating industrial districts (Sabel 1989).

Here, a number of different issues and forms of quasi-integration may be distinguished. First, what do we mean by "quasi"-integration, and what forces are encouraging this form of industrial organization? Most proponents of the notion of post-Fordism simply assume the superiority of small or medium-sized firms as the outcome of "specialization" made possible by the new technologies. In the Coase-Williamson paradigm, there is only one alternative for the firm: make or buy, market or hierarchy. It is advantageous to buy when the price of independent production plus the transaction cost is less than the costs of production and hierarchy within the firm. Since flexible specialization is based on production systems which enjoy important external economies of scope and significant costs of organization, vertical integration would efface the advantages of economies of scope (because of the rigidity and specificity of intermediate production) and would dramatically increase the costs of organization in the form of hierarchy. Hence the victory of market over hierarchy.

There is a grain of truth in this analysis. As Leborgne (1987) has shown, flexible machinery entails a new solution, a compromise between integration and disintegration in terms of production and organization costs, in which the specialized firm (or plant) minimizes the costs of organization, maximizes economies of scope through "modular" integration, and allows for the tight control on quality, at the same time that it fosters innovation. Nonetheless, minimizing costs is not the main problem for capitalist production. Maximizing profits, or more precisely the rate of profit, is the great imperative forgotten in the Coase-Williamson paradigm. In this respect, there exist important differences between "make" and "buy." In the first case, the principal firm invests the fixed capital and controls the value added by its own workers. In the second case the principal shares with the contractor the cost of fixed assets, but it has to give up the surplus-value of the contractor's workers.

This points up the specific advantages of quasi-integration. As Leborgne (1987) and Laigle (1989) have shown, "quasi" refers to both the production process and valorization process. In the valorization process, the validation of fixed capital and labor committed to production by the subcontractor is achieved via routinized interdependence between the two firms (one being a regular supplier/customer of the other). Both of them depend upon the productive complementarity of their assets and know-how. Quasi-integration minimizes both the costs of coordination (because of the autonomy of the specialized 
firms or plant), and the costs of information/ transaction (because of the routinized justin-time transactions between firms). Moreover the financial risks of $R \& D$ and investments are shared within the quasi-integrated network. 17

Yet there are important differences between types of quasi-integration. In a first (extreme) case, the buyer has at its disposal the know-how of the subcontractor (because the product is standardized, or because the quasi-integration is the result of disintegration of the principal firm). The former is then in a position to induce the latter to invest without guaranteeing its outlets, and also in a position to contract at a price which transfers to it the value added produced by the subcontractor. This case may be properly labeled "vertical quasi-integration." By contrast, when partnership and strategic alliance link a supplier with specific technology to a regular customer of another sector of the division of labor (for instance Mercedes and Bosch, or Aerospatiale and SNECMA), we have a case of "horizontal quasi-integration." The general case, of course, is intermediate: "oblique quasi-integration." 18 For instance, the link between Renault and its seat-maker is oblique because Renault orders for specific goods which are part of the process of production of cars (and were formerly produced in integrated car factories), but the seatmaker is fully responsible for the process of production of the seats (including subcontracting the production of metal frames, fabrics, and so on). As Laigle (1990) has shown in the case of the French car industry, the concrete network of quasi-integration is a mix of horizontal, vertical, and oblique ties (Figure 17.2). The more horizontal the tie, the better the bargaining power of the supplier, but also the more research and development in its product (this being both the cause and the effect of its power), hence the higher quasi-rent earned by the network. ${ }^{19}$

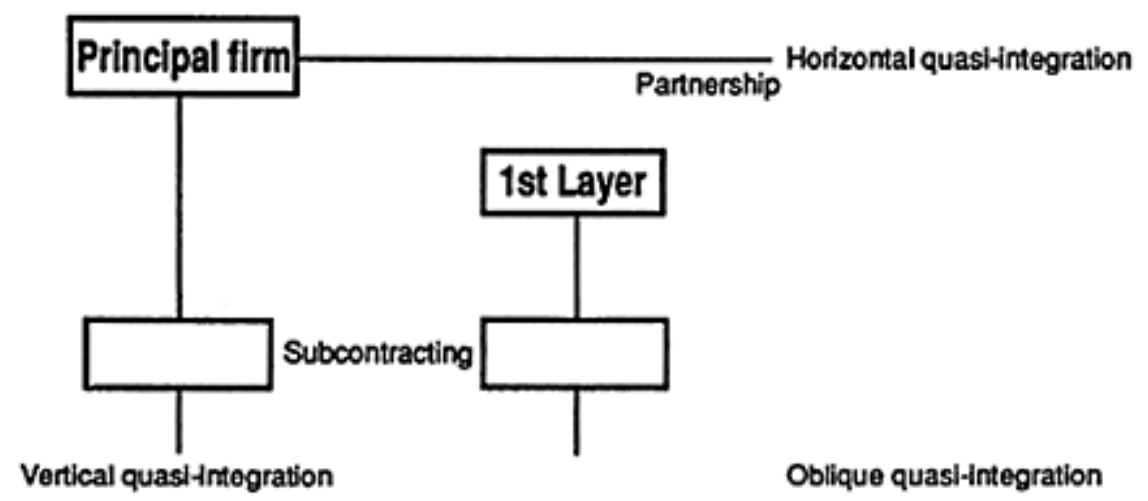

Figure 17.2 Post-Fordist industrial organization

There is a striking resemblance between Figures 17.1 and 17.2. In both cases, the vertical axis represents a form of "flexibility," which increases the share of surplus value accruing to the principal on the basis of direct control over the dominated agent. In both cases, the horizontal axis represents a form of autonomy of this agent, implying a higher efficiency of the principal-agent couple. In other words, quasi-integration is always cost-minimizing à la Williamson, but VQI is revenue-maximizing only for the principal, while OQI and 
partnership are revenue-maximizing for the whole network.

Our thesis (developed in Leborgne and Lipietz 1987, 1989) is twofold. First, this apparent correspondence is real. The tendencies toward negotiated involvement in labor relations and toward partnership in industrial organization seem to be different expressions of the possible formation of an historical bloc which is modernizing certain economies. There are territories where dense, horizontal forms of quasi-integration between firms develop in pace with negotiated involvement within firms, while in other places vertical disintegration (mostly toward other low-wage regions) develops in pace with neo-Taylorism. ${ }^{20}$ Second, these two combinations correspond to two different pathways of development, and the first is presently outperforming the second.

Thus, care should be taken when heralding the benefits of industrial districts. In many cases, a hidden subordination through VQI of most firms to a principal firm is likely to emerge (e.g. of the firms of the Third Italy to those of the First Italy). The nature of quasi-integration determines whether the district is a progressive or a regressive evolution from the staff-and-line industrial organization of Fordism. Subcontracting to poorly integrated districts remains consistent with neo-Fordism.

\section{MACROECONOMICS STILL MATTERS AS WELL AS ECOLOGY}

The euphoric diagnoses of post-Fordist "possibilities for prosperity" have been strongly criticized on the basis of their lack of concern with social aspects of "really existing flexible specialization" (as Brezhnev used to speak of "really existing socialism"). As Jensen (1989) and Pollert (1988) have pointed out, there is a real danger that "negotiated involvement" in "yeomen democracy" would be restricted to a yeomanry, a male aristocracy of skilled workers.

A clear distinction must be made between an analysis of existing reality and its problems, and the creation of political options for gender and racial equity. Negotiated involvement of workers entails in itself neither social polarization nor equalization. Here, the scope of the negotiation will be determinant, and that will be subject to a major political and cultural struggle. ${ }^{21}$ In the present situation where the word "flexibility" is used in a confusing way to extol the virtues of neo-Taylorist, Toyotist, and Kalmarian models, conceptual clarification is first needed. The first class of models, which includes individually negotiated involvement, will be favored where an individualistic vision of society is accepted, and will induce social polarization. Kalmarian models on the contrary will be favored when anti-egalitarian social consequences are rejected. Toyotism (that is, firm-level negotiated involvement in "good" firms and neo-Taylorism elsewhere) will be accepted in hierarchical societies acknowleging "natural" differences between individuals and genders. Flexible specialization as a technological paradigm has little influence there.

Nonetheless, the theory of flexible specialization is to be criticized when it professes a benign neglect of macroeconomic issues:

A shift away from mass production would restore the neoclassical equilibrating mechanisms that were probably most prominent in the early-nineteenth century American economy.... It would be possible to maintain full employment 
without resorting to wage determination systems linking purchasing power to the rate of increase of productive capacity.

(Piore and Sabel 1984:276).

This is an amazing statement based on a completely unrealistic assumption about declining economies of scale in a highly capital-saving paradigm. In fact, flexible specialization, as we have already noticed, is more likely to be based on costly assets, resting on huge and risky investments in research and development. If a massive demand (even a fragmented one) is not secured through some form of regulation of the sharing of gains of productivity, the old instability of pre-Fordist capitalist economies is likely to come back. Macroeconomics still matters.

Macroeconomic constraints are well kown by economists; they can be logically deduced. We may thus be very brief. First, any model of development must be profitable. Second, it must be competitive. Third, demand must match supply.

Assuming that "involvement" is more productive that neo-Taylorism, the first constraint suggests that, when a great part of the surplus has to be reserved to debt servicing, there is little room for "negotiating involvement" because the wage has to be as low as possible. The existing debt load on a given country is thus inducing neoTaylorism. For the second reason, countries which are already pursuing neo-Taylorism, and are less productive than "involving" ones, are also handicapped in the search of a better capital-labor truce. This does not imply that the roll of the dice is already over: equivalents may be proposed to workers (such as rigid wage contracts). Still such countries as the USA, the UK, Brazil, and Eastern Europe will have difficulties in shifting toward the Kalmarian paradigm. On the contrary, Scandinavia, Germany, Japan, and even Korea (which is developing specific forms of "involvement" in the male sector of its labor force), may be considered to be marching toward the twenty-first century in a good position.

As far as demand is concerned, the Kalmarian paradigm offers greater possibilities to regulate social demand than neo-Taylorism. ${ }^{22}$ The latter will be associated with a cycle of "exhilarating" periods of boom (with an increase of profits and of the revenues of the upper tier of society) and periods of depression (due to overinvestment or "cooling off" policies): the return of the business cycle, as opposed to the more regular pattern of Fordism.

This brings us back to the problem of "yeomen democracy," even when workers' involvement is negotiated firm-by-firm. This is what Aoki (1988) has labelled "the dilemma of worker democracy." In this case, the surpluses of productivity are specific to the firm, and the resulting quasi-rent of the firm exists insofar as differential productivity is maintained vis-à-vis other competitors. The negotiated compensations (in terms of higher wages, reduction of labor time, or lifetime career) are limited to this quasi-rent. In this condition, when cyclical downturns on the market occur, insiders and management will be allied against newcomers, subcontractors, and competitors. This tends to consolidate a "workers' aristocracy" at the top of the generalized, pragmatic, meritocratic hierarchy in the whole society. ${ }^{23}$ This hierarchy may develop into a completely dualistic structure (negotiated involvement/neo-Taylorism), especially when gender or ethnic differences come into play. In this case, any increase of the aggregate domestic demand 
would be restricted by the need for competitivity of this dualistic structure, since it is dependent on external outlets. ${ }^{24}$ Things are different when a general (and global) growth in hourly labor-cost is a rule imposed upon any competitor. Then the issue is not the sharing out of specific quasi-rent (or "extra surplus-value" in Marxist terms), but a general redistribution of gains in social productivity ("relative surplus-value"). So, not only does macro-economics matter, but it has a strong effect on the social character of post-Fordism.

Up to now, nothing has been said about the nature of the redistribution of the gains in productivity accruing from "negotiated involvement": growth in purchasing power? In free time? Here a major new constraint appears at the dawn of twenty-first century: ecological sustainability. Capitalist development not only degraded work under Taylorism (Braverman 1974); we now understand how much it degraded the earth, according to Marx's prophecy (and this is also true in the state capitalism of the East). In fact, capital/labor conflicts have been allayed for the most part at the expense of nature, hence at the expense of future generations. The hole in the ozone layer and the greenhouse effect are among the consequences of the great industrial boom of the Fordist and Soviet models. The recovery of the 1980s has increased the frequency of industrial disasters, and it is worsening the global ecological crisis. The limits of any productionist model are fully revealed, at the local or global level, and the necessity for future models of development to be sustainable, that is ecologically consistent, is ever clearer. ${ }^{25}$

If we assume the continued development of ecological concern all around the world (and this is the case in the West, in the East, but less in the South), sustainability will become a new factor of legitimation of future capital-labor compromises. As a result the counterparts of gains in productivity, if they are negotiated, will tend to be granted in the form of an increase of free time rather than in the form of an increase in real wage (as in Fordism). That solution may prevail in the most socialized form of Kalmarian compromises. ${ }^{26}$ Another solution, consisting of alleviating the damage to the environment through ecologically sensitive industries, would be favored by an overconsuming upper tier attached to neo-Taylorism or Toyotism. This would raise the relative prices of consumption goods to the detriment of the lower tiers of the society. Ecology would provoke a major distributional conflict.

\section{TOWARD A CORE-PERIPHERY CONFIGURATION IN POST- FORDIST TIMES?}

We have been accustomed to thinking that one model of capitalist development should be hegemonic in any given historical period. This was true at the time of British hegemony (competitive capitalism with extensive accumulation), and it was true at the height of Fordism. In these times, countries which failed to adopt the dominant model were locked out of world industrial competition. In its Golden Age from 1950 to 1970, Fordism defeated and marginalized Sovietism and corporatist forms of import substitution in the Third World. As far as manufactured tradable goods were concerned, Adam Smith's law of "absolute advantage" seemed to prevail: Fordist models of production outperformed all others. Thus, non-Fordist countries were restricted to primary goods exports and could 
only develop industries via protectionism.

The crisis of the 1970s changed all that. New industrial powers emerged from the South, with new models of development ${ }^{27}$ combining Taylorism and flexible forms of the wage contract. Nowadays, industrial protectionism has changed direction: high-wage developed countries are protecting themselves against "unfair" competition of these countries with slighly lower productivity but much lower wages.

In the first half of the 1980s, supply-side, neo-Taylorist policies were designed to cut labor costs. Yet, as we have already seen, more advanced social compromises performed very well in the "post-Fordist" countries, either in the form of Toyotism or Kalmarism. Moreover, the trade deficit of the more neo-Taylorist countries (such as the USA and UK) opened huge outlets for the more competitive production of Japan and WestGermany (Lipietz, 1989b). Such a macroeconomic world situation is not stable. Too many countries have a debt to pay: the USA, the UK, the Third World, and Eastern Europe. Should they try to do it through a new offensive in "external flexibility," with more unemployment and lower wages, a new world depression could threaten the prosperity of negotiated involvement.

Protectionism may be a solution, but it is not the main tendency. On the contrary, the desperate attempts of Third World to pay its debt, the necessity for the United States to balance its external accounts, and the integration of the ex-socialist world into the world economy will increase world competition. From the experience of the 1970s and 1980s, it is doubtful that either neo-Fordism or post-Fordism will completely eliminate the other. Thus, the main question is how the two models will function within the same trading system, such as the EC (and its eastern satellites). We may assume that in labor-intensive routinized sectors, neo-Taylorism may dominate negotiated involvement at a sufficiently low wage. Then, as envisioned by Ricardo's theorem on comparative advantage, countries (or regions) will tend to specialize in sectors where they are comparatively best "endowed," whether in flexibility and low wage_or in involvement. In that case, the total amount of demand will be limited by wage competition due to the coexistence of low-wage, low-involvement regions and higher-wage, higher-involvement regions. The greater the possibility to practice neo-Taylorism, the smaller will be the islands of "yeoman' democracy" á la Piore and Sabel, and lower overall global prosperity.

The most likely scenario is the formation of a new world economic hierarchy. It will not oppose an industrial Fordist core to a primary-goods-producing periphery, but will present itself as a de facto new industrial division of labor. The core economies will be those having adopted a Kalmarian compromise in much part of their production, with a possibility of internal dualism (Kalmarism/neo-Taylorism). They will dedicate themselves to high-technology and highly skilled production. The periphery will consist of economies organized according to the neo-Taylorist paradigm, and dedicated to routinized and labor-intensive activities. Intermediate regions (with very wealthy high technology and financial sectors) may develop out of individually negotiated involvement (the "Californian type" defined in Leborgne and Lipietz, 1987).

In this new world industrial hierarchy, some former core economies may become semiperipheral, including the UK, France, and even many states of the USA. Conversely, Japan and Germany will consolidate their places in the core, with some other former core economies like Sweden, and some formerly peripheral ones catching up, such as Korea 
following the trajectory of Finland. A part of Eastern Europe would be involved in this process, while the rest of it would become a peripheral to Germany and Japan. As for the Third World, a part of it is becoming marginalized, and another part is becoming integrated into the world economy as a neo-Taylorist (or even primitive Taylorist) subcontracting area around the more advanced growth poles.

\section{CONCLUSIONS}

History is alive again. On the ruins of Fordism and Stalinism, humankind is at a crossroads. No technological determinism will light the way. The present industrial divide is first and formost a political divide. The search for social compromise, around ecological constraints, macroeconomic consistency, gender and ethnic equality, all mediated by the nature and degree of political mobilization will decide the outcome.

In the field of industrial relations, external flexibility will compete with negotiated involvement. In the field of industrial organization, oppressive worldwide subcontracting will compete with dense, territorially based partnership. The macroeconomics of the future may be based on a downward spiral of social and ecological competition, leading to recurrent financial, business and environmental crises, or an ecologically sustainable and macroeconomically stable model. As usual, reality will consist of a mix, with a coreperiphery structure along geographical, ethnic, and gender lines. Radical economists and geographers may be part of finding the better pathway, both by identifying the possibilities for prosperity and by criticizing unrealistic optimism for flexibility as a panacea. 